\title{
The Principal's Supervision to Improve Teacher Professionalism
}

\author{
Hendri Yazid; Sufyarma Marsidin; Rifma \\ Jurusan Administrasi Pendidikan, Fakultas Ilmu Pendidikan, Universitas Negeri Padang, \\ Jl. Prof. Dr. Hamka Air Tawar Barat Kota Padang, Indonesia \\ e-mail: hendriyazid75@gmail.com1,sufyarma@fip.unp.ac.id2,rifma34@fip.unp.ac.id3
}

Article received: July 2021; revised: July 2021 ; accepted: August 2021

DOI : 10.17977/um025v5i32021p137

\begin{abstract}
This study aimed at determining the program, implementation, evaluation, and looking at the supporting and inhibiting factors faced by the school principal of Madrasah Aliyah in carrying out their duties as supervisors. The method used in this study is qualitative with a descriptive approach. This study is conducted in Madrasah Aliyah Negeri 3 Padang. Meanwhile, for data collection techniques, this study employs observation, interviews, and documentation with the research subject of madrasah principal, vice-principal of the madrasah, and teachers totaling 49 people. Data analysis is executed by reducing, displaying, drawing conclusions, and verifying data. It was found that the supervision program was established at the beginning of the year through meeting activities involving all madrasah personnel which was carried out according to a predetermined schedule. Supervision is carried out on individual teachers and groups with class visits, teacher meetings, group discussions, exchange of experiences, and seminars. Supervision evaluation is carried out at the end of each semester by improving the goals that have not been achieved and making improvements in the preparation of the next program. The supporting factor for the implementation of supervision is the teacher responding positively and the establishment of a good relationship between the madrasah principal and the teachers so that it raises the awareness of the teachers to improve their abilities. Meanwhile, the obstacles in this study were the implementation of this supervision are due to the busyness of the madrasah principal and the absence of the teacher when the supervision is carried out.
\end{abstract}

Keywords: Supervision; Madrasah principal; Teacher professionalism

the quality of education on the scale of national is still a crucial problem and a major problem in this country. The problems and challenges of the quality of education show how education management requires a serious and systematic handling pattern and mature conditioning (Sumarsono, et al., 2019). Education is something that is needed by someone in fostering and establishing a better person, with education, a person can have insight and knowledge that is used as a guidance and guide in his life. Education is an activity to provide knowledge from teachers to students, teachers as educators provide knowledge to students in growing student knowledge, with education can grow and develop existing values that apply in everyday life. This value is similar to the goal of education, namely to grow students' insight, skills, and behavior to the maximum. Educational activities can trigger a good personality in the students so that they can grow their identity, expertise, and individual potential.

Education is a learning activity carried out by providing insight so that it can foster a way of thinking, feeling, and its function and role in life. This description is illustrated in the Law of the Republic of Indonesia Number 20 of 2003 concerning the National Education System, in Chapter, I Article 1 Paragraph (2) it is stipulated that "National education is education based 
on the 1945 Constitution which is rooted in religious values, Indonesian national culture and responsive to changing times, it provides knowledge and insight to individuals regarding the knowledge and skills, values and behaviors needed to work optimally. National education also guides the creation of individuals who can participate in the life of the nation's community.

Madrasah institutions are the institutions implementing the lessons that guide learning activities to achieve educational goals. Educators are used as determinants of the quality of education because the educators are the givers of insight and role models of behavior in a person. Success in the implementation of lessons greatly affects the quality of education because the educators can transfer or provide directive knowledge to students in improving the quality of teaching.

The success in improving the quality of teaching depends on the policies and leadership of the madrasah principal. According to Suryosubroto (2010), the principal is a leader who is used as a reference for personnel and staff in the school environment, also $\mathrm{s}(\mathrm{he})$ should provide examples and good guidance in achieving the goals of implementing education in schools to the fullest. Meanwhile, Kusumaningrum, et al. (2019) stated that teacher performance does not appear automatically, but needs to be identified, facilitated, and developed, and maintained to achieve school goals. Therefore, the principal as the highest leader in school institutions needs to know the determinants of performance to encourage and even boost their performance to the best.

The principal of the school/madrasah is the center of the leader who guides and organizes school/madrasah activities so that they can experience better changes. That is, the principal has responsibility for the quality of the performance of the educators, so that the educators have enthusiasm and professionalism in carrying out lessons, and have the competence to increase the creativity of educators in explaining teaching materials to students. The principal of the school/ madrasah becomes a reference in school institutions that have a very large responsibility in the development of the progress of the implementation of lessons in schools. The responsibility of the madrasah principal for the improvement and progress of the implementation of lessons refers to the program that has been determined. The same thing was conveyed by Kusumaningrum (2020) that the principal is responsible for communicating goals, which must be widely known and supported throughout the school.

The head of the madrasah as a leader in learning institutions has a great responsibility for the success of educational institutions. The principal has a role in implementing, guiding, improving, developing, and providing motivation in creating good interactions, providing proper supervision and supervision in the design time.

The head of the madrasah, as a supervisor, has a role in establishing and developing the potential of the educators in the implementation of lessons in school institutions and has a great responsibility in developing and advancing the school. Therefore, the principal is required to carry out rapid supervision based on appropriate procedures and techniques, so that teacher's competence will increase. One of the competencies that need to be improved in terms of supervision activities as pedagogical competence. This competence will lead to the quality of learning carried out by the teachers. The same thing was conveyed by Sumarsono, et al. (2021) that pedagogical competence is basically an ability that must be possessed or mastered by educational staff (teachers/lecturers) in managing learning. This competency is a typical competency that distinguishes the teaching profession from other professions and will determine the level of success of the process and student learning outcomes.

According to Sergiovani as cited in Mulyasa (2007), supervision is an activity that is made to help educators and supervisors to provide knowledge to educators or supervisors about the demands of being an educator so that they can carry out lesson delivery and improve the ability of students and provide good guidance. 
The guidance carried out by the principal who is given to the educators can heal and develop the performance of the educators in carrying out their duties. The supervisor's task is to provide encouragement and support to the educators that learning activities can develop skills, knowledge, skills, behavior, and educational experience in learning activities, it was carried out by well-assisted education, so that education can improve its performance in carrying out its duties, namely to improve knowledge and skills in learning activities.

The educators are also very instrumental in developing and improving the quality of learning implementation. Futesna, et al. (2019) mentioned that teachers are the main actors in educational programs in schools to achieve educational goals. The quality of the educators is required to improve and develop fun and meaningful learning, and it can develop good outputs. This is in line with the opinion of Idris (2007) that if the quality of an educator in the learning implementation can be achieved the lesson objectives, it means that $\mathbf{s}(\mathrm{he})$ is a professional educator. This is because the educators have expertise in implementing lessons that can create an atmosphere and development of subject matter that matches the established curriculum.

The results of interviews and observations with the madrasah principal and several educators revealed teacher problems in improving the quality of education, especially in teaching and learning activities in accordance with current educational developments. In efforts to solve these problems, it is necessary to improve the implementation of lessons, making instruments, as well as appropriate learning methods and media. One solution to realize these improvements requires a coaching program or supervision of teachers. With the implementation of supervision carried out in a programmed and scheduled manner, learning problems will be resolved and of course, the quality of learning will increase.

\section{METHODS}

This study employs a qualitative method with a descriptive approach, this is because the research carried out tends to dig up a lot of information, so that it can describe the phenomena that occur indepth and thoroughly. A lot of information is obtained during the research process, so that investigations require in-depth observations and in natural conditions. According to Moleong (2011), one of the characteristics of qualitative research is concerned with the process. Meanwhile, according to Ulfatin (2015: 24) qualitative research is a study to understand the phenomena that occur. It can be in the form of behavior, perception, motivation, action, and others holistically by using descriptive methods in the form of words and grammar by utilizing various scientific methods.

The research is located in Madrasah Aliyah Negeri 3 Padang. Because this research was conducted in one school, the type of research used in this study was a case study. According to Sugiyono (2011), qualitative research using case studies means that research is focused on only one phenomenon that is selected and wants to be understood in depth. Meanwhile, for the data collection techniques, this research uses observation, in-depth interviews, and documentation studies with the research subjects of the madrasah principal, vice-principal, and teachers totaling 49 people. Data analysis is executed by reducing, displaying, drawing conclusions, and verifying data.

\section{RESULTS AND DISCUSSION}

The preparation of the supervision program by the principal of Madrasah Aliyah Negeri 3 Padang was carried out at the beginning of the new school year through holding meetings by involving all levels in the school. The supervision program is outlined in the annual program and semester program. The program was designed to form a group or implementing a team in supervision activities. The supervision program includes academic or learning supervision activities and administrative supervision. The supervision program is established to encourage teachers in the learning process and improve service quality. To see the effectiveness of the supervision program, an assessment is carried out and follows up on the results of supervision. 
Supervision is carried out following the schedule that has been determined and ratified in the Decree. Before the implementation was conducted, the madrasah principal or senior teacher who has been given the mandate/authority to carry out supervision communicates supervision activities to the teachers or conducts initial meetings, and prepares the supervision instruments used. Supervision strategies or techniques are carried out individually and in groups, either directly or indirectly. Individual strategies or techniques are carried out by conducting class visits, meanwhile, the implementation of group supervision is carried out through meetings, discussion forums, and seminars.

To determine the effectiveness of supervision, supervision activities are evaluated at the end of each semester. The results obtained are informed to the teacher both individually and in groups. The results of the assessment will be improved or developed if the objectives have been achieved, the weaknesses will be observed, and changes will be made in the formulation of the program in the following year.

Supporting factors in supervision activities include 1) teacher enthusiasm for programmed supervision, 2) good interaction between teachers and principal, and 3) teachers' awareness in improving and developing their abilities through supervision activities. The inhibiting factors are: 1) at the time of supervision, sometimes the teachers cannot attend school due to illness or other activities, such as attending training, and 2) the headmaster is busy.

\section{Preparation of the Supervision Program by the Madrasah Principal}

The supervision program can increase and develop teacher's skills in explaining and implementing the curriculum into semester programs as well as making designs in the learning implementation, assessing the implementation of lesson activities, designing and selecting learning instruments properly and correctly following the teaching materials that will be explained during the implementation of lessons.

This illustration is reinforced by Soetjipto and Kosasi (2009) who stated that the responsibilities of a supervisor in assisting education are: 1) Curriculum development. The curriculum must be improved and developed as a whole which aims to assist the educators in implementing and adapting lesson skills planning to create an attractive learning environment for students. 2) Teaching organization. Supervisors play a role in guiding and providing direction in carrying out learning activities, so that students, educators, and facilities and infrastructure in learning activities are in accordance with the predetermined duration to achieve the desired goals. 3) Provision of infrastructure that can support the implementation of learning activities. 4) Planning of teaching materials that progress in the determined curriculum. Education can carry out assessments and improvements regarding the subject matter to achieve the objectives in the lesson. 5) Design and implementation to develop learning skills and performance of the educators in the learning implementation. The implementation is such as assistance in carrying out seminars or workshops, consultations, work tours, and various types of training in positions. 6) Lessons application in the fulfillment of tasks and evaluation of activities. The educators must be equipped with information that is in accordance with teaching materials or the demands of their responsibilities. 7) The adjustment of the learning implementation with the guidance implementation provided by school agencies to students. 8) The improvement of good interaction with the community environment is related to the learning implementation. 9) Assessment activities in learning, especially in designing, selecting learning media, grouping, and determining the stages in data collection, observation and interaction from the results of data collection, and decision making for improvement of learning implementation activities.

The statement can be seen that the supervision program includes the learning implementation in changing and improving the performance of the educators to improve and create a learning atmosphere for which they are responsible to the supervision program aims at the activities of fostering educators who encourage the improvement and development of performance potential in the implementation of teaching.

\section{The Implementation of Supervision}

Supervision is carried out by the madrasa principal or senior teacher who has been assigned to provide guidance and coaching to the educators so that they have professional performance in carrying 
out all their responsibilities. This description is in accordance with the opinion of Soetjipto and Kosasi (2009) who argued that the readiness of supervisors in conducting observations and research on attitudes towards the implementation of lessons as well as the readiness of supervisors in providing direction, guiding, and fostering teachers will improve teacher professionalism.

Coaching and mentoring for educators have an impact on the success and achievement of learning activities. In the implementation of supervision activities, cooperative behavior needs to be shown between the supervisors and teachers, so that it will provide an overview of the results of supervision that still need to be improved. Talib, et al. (2019) said that the principal as a leader has to provide a sense of trust and satisfaction both in the performance and results of the performance of his/her teachers. And don't forget to involve them in various school activities, especially in decision making.

\section{The Evaluation of Supervision in Improving Teacher Professionalism}

Evaluation is the implementation that is planned in understanding the conditions by requiring the media and the achievement of the implementation that is used as a reference in reaching a conclusion. According to Djudju (Daryanto, 2007) evaluation is the implementation in assessing the knowledge of individuals and groups. The function of evaluation is to analyze an object or atmosphere in obtaining appropriate information in solving a problem. Evaluation on supervision is the activity of information obtained to be used as a reference in improving the teaching and learning process in the next semester. The material obtained is then used in designing the implementation and planning of the program. Supervision evaluation is to respond to educational supervision activities that aim to create the maximum learning process and can improve the learning process in obtaining the successful implementation of the specified lessons.

\section{Supporting and Inhibiting Factors in the Implementation of Supervision}

In the implementation of supervision activities, of course, there are various problems or inhibiting factors. Of course, the inhibiting factor must immediately find a solution, so that it will not have a significant impact. In solving obstacles, Mukhtar and Iskandar (2009) suggested that a supervisor must provide interesting and useful solutions for the educators. The illustration above guides the madrasa principal to pay attention to how the talents and individual resources of the educators can become a reference for other educators in carrying out the desired teaching and learning activities. Saud (2009) stated that efforts in smoothness and achievement of success in solving a problem faced by the teachers in the implementation of the supervision of the principal are: (1) implementing the vision and mission equation, (2) good supervision management, (3) involving educators in supervising activities. , and (4) involving educator organizations, such as the Teacher Activity Center (PKG) and the Teacher Activity Group (KKG). Regarding this, the research results of Saputra, et al. (2019) showed that the principals apply an approach strategy as a leader and family with various aspects of consideration of the problems that are being faced by the teachers in schools.

Madrasah principal is required to solve the problems that exist around education, think concretely and mediate in solving problems, and take satisfactory action for education staff. The madrasah principal is in charge of carrying out supervision in the form of providing motivation, direction, supervision, and evaluation of problems related to the learning process and the educational process in fostering a pleasant learning atmosphere. The madrasah principal is the determinant in making a madrasah policy so that problems in the implementation of the supervision program will be resolved. This is in line with the research findings of Anam, et al. (2019) which showed that the principal is the determinant and the center of the main policymaking and making in the academic field of schools.

The research results are in line with the research findings of Maharwati (2020) that the implementation of the primary school principal's academic supervision includes group supervision and individual supervision. The strategy for implementing the principal's academic supervision in the implementation of group supervision is carried out through Teacher Working 
Group activities and individual supervision through scheduled supervision activities in odd or even semesters and clinical supervision. Supporting factors in the implementation of the principal's academic supervision are the high concern of the principal in the implementation of supervision, the high motivation of teachers in the implementation of supervision, and the availability of adequate facilities and infrastructure in the implementation of supervision.

The research findings are also in line with the study results of Abadi et al. (2019) that the madrasah principals in carrying out the supervision of learning in accordance with the plans outlined in the supervision program, using instruments and observation sheets, using supervision principles, using varied techniques and approaches and carried out in a pleasant atmosphere. The madrasah principal is required to take strategic steps as an embryo of success in the implementation of learning supervision in the schools. The results of the study are also in line with the findings of Wiyono et al. (2017) which showed that the implementation of instructional supervision consisted of the group and individual supervision techniques, with planning, implementation, evaluation, and follow-up steps.

\section{CONCLUSION}

The supervision program is carried out in the new teaching by holding meetings that involve all teaching personnel consisting of annual programs and semester programs. The program design is to create an organizational structure for knowledge supervision, form a group, and establish a Decision Letter (SK) on the implementation of tasks in learning supervision activities, administrative supervision, as well as learning activities, counseling services, assessment of supervision activities, and carrying out a follow-up on supervision results.

Supervision is carried out by referring to the schedule set out in the Decree. Before the implementation of supervision, the madrasah principal explained the supervision activities and presented the media for the supervision activities. Supervision is carried out individually or in groups with visits, communication, educator meetings, and discussions as group activities, deliberation, discussions, and seminars.

The evaluation of the supervision program is carried out at the end of the school year by conveying it to the teachers, both individually and in groups. The results of the evaluation can be improved or developed if the learning objectives have been obtained, while the obstacles and weaknesses can be observed in improvements in the design of the next year's program.

Supporting factors for supervision activities, namely the teachers accept positively about supervision activities, establish good interactions between teachers, madrasa principals, and teachers to create teacher awareness in growing and developing their knowledge and experience. While the inhibiting factors or problems in carrying out this supervision are teachers who do not arrive on time for supervision activities due to illness, permission or attending other activities, and sometimes the madrasah principal is busy. It is recommended for further researchers to conduct an in-depth study of the supervision carried out by the madrasah principal in establishing and developing the teacher's professionalism towards the educational achievements given to the students.

\section{REFERENCES}

Abadi, Y., Akhyak, A., Fuadi, I., 2019. Supervisi Pembelajaran Kepala Madrasah dalam Meningkatkan Mutu Pembelajaran. JMSP (Jurnal Manajemen dan Supervisi Pendidikan) 3, 36-44. https://doi.org/10.17977/ um025v3i22019p036

Anam, M.K., Mustitingsih, dan Sumarsono, R.B., 2019. Kepemimpinan Kepala Sekolah Dalam Pembuatan Keputusan di Sekolah Berbasis Pesantren. JAMP: Jurnal Asministrasi dan Manajemen Pendidikan, Volume 2, Nomor 2. http://journal2.um.ac.id/index.php/jamp/article/view/7457

Daryanto. 2007. Evaluasi Pendidikan. Jakarta: Rineka Cipta.

Futesna, A.D., Wiyono, B. B., Sumarsono, R. B., dan Supriyanto, A. 2019. Analysis of Factors that Form Teacher's Discipline Behavior in Public Junior High School. Advances in Social Science, Education and Humanities Research, volume 38 . 
Idris, J. 2007. Analisis Kritis Mutu Pendidikan. Banda Aceh: Taufiqiyah Sa’adah.

Kusumaningrum, D. E., Sumarsono, R. B., dan Gunawan, I. 2019. Professional Ethics and Teacher Teaching Performance: Measurement of Teacher Empowerment with a Soft System Methodology Approach. International Journal of Innovation, Creativity and Change, Volume 5, Issue 4, Special Edition: ICET Malang City, 2019. www.ijicc.net

Kusumaningrum, D. E., Sumarsono, R. B., dan Gunawan, I. 2020. Pengaruh Kepemimpinan Pembelajaran, Kepemimpinan Perubahan, Kepemimpinan Spiritual, Budaya Sekolah, dan Etika Profesi terhadap Kinerja Mengajar Guru. JMSP (Jurnal Manajemen dan Supervisi Pendidikan) Volume 4 No. 3 Juli 2020. http:// journal2.um.ac.id/index.php/jmsp

Marhawati, B., 2020. Pelaksanaan Supervisi Akademik Kepala Sekolah Dasar: Studi Kualitatif. JMSP (Jurnal Manajemen dan Supervisi Pendidikan) 4, 71-76. https://doi.org/10.17977/um025v4i22020p071

Moleong, L.J. 2011. Metodologi Penelitian Kualitatif Edisi Revisi. Bandung: PT. Remaja Rosdakarya

Mukhtar dan Iskandar. 2009. Orientasi Baru Supervisi Pendidikan. Jakarta: Gaung Persada.

Mulyasa. 2007. Menjadi Kepala Sekolah Profesional. Bandung: Remaja Rosdakarya.

Rivai, M dan Murni. 2009. Education Management (Analisis Teori dan Praktek). Jakarta: Rajawali Pers.

Rukajat, A. 2018. Penelitian Kuantitatif “Quantitative Research Approach.” Deepublish.

Sahertian, P. A. 2008. Konsep Dasar dan Teknik Supervisi Pendidikan dalam Rangka Pengembangan Sumber Daya Manusia. Jakarta: Rineka Cipta.

Saputra, R. B., Adha, M.A., dan Sumarsono, R.B., 2019. Strategi Pendekatan Peran Sebagai Pemimpin dan Keluarga yang Diterapkan Kepala Sekolah untuk Meningkatkan Komiutemen Kerja Guru di Sekolah. Kelola: Jurnal Manajemen Pendidikan, Vol.2 Nomor. 6.

Saud, U. S. 2009. Pengembangan Profesi Guru. Bandung: Alfabeta.

Soetjipto dan Kosasi, R. 2009. Profesi Keguruan. Jakarta: Rineka Cipta.

Sugiyono. 2011. Metode Penelitian Kuantitatif, Kualitatif dan R\&D. Bandung: Afabeta.

Sumarsono, R.B., Imron, A., Wiyono, B.B., dan Arifin, I. 2019. Strategi Kepala Sekolah dalam Mengoptimalkan Partisipasi Orangtua untuk Meningkatkan Kualitas Sekolah. Jurnal Manajemen dan Supervisi Pendidikan, Vol.4, No.1. http://journal2.um.ac.id/index.php/jmsp/article/view/9772

Sumarsono, R. B., Gunawan, I., Kusumaningrum, D. E., Benty, D. D. N., dan Bhayangkara, A. N. 2021. Influence of Lecturer's Pedagogic Competency Level, Quality of Administrative Services, Completeness of Lecture Supporting Facilities, and Student Satisfaction on Learning Motivation. Jurnal Ilmu Pendidikan (JIP), Vol. 27, Issue 1, June 2021, pp. 23-33. http://journal2.um.ac.id/index.php/jip/article/view/16842

Suryosubroto. 2010. Manajemen Pendidikan di Sekolah. Jakarta: Rineka Cipta.

Thalib, D., Fitirana, D., Maisyaraoh, dan Sumarsono, R. B., 2019. Atribusi Bawahan terhadap Pemimpin Berkarisma. Tarbawi: JurnalKeilmuan Manajemen Pendidikan. Vol. 5 No. 02, Desember 2019, 205-216. http://jurnal.uinbanten.ac.id/index.php/tarbawi

Ulfatin, N. 2015. Metode Penelitian Kualitatif di Bidang Pendidikan: Teori dan Aplikasisnya. Malang: Media Nusa Creative.

Undang-Undang Republik Indonesia Nomor 20 tahun 2003 tentang Sistem Pendidikan Nasional.

Wiyono, B.B., Kusmintardjo, Sucipto, 2017. The Effective Supervision Techniques that Influence Teacher's Performance. Man in India, 97(24), 25-33. https://serialsjournals.com/abstract/33975_3.pdf. 